\title{
Range research: The second generation
}

\author{
JAMES A. YOUNG AND CHARLIE D. CLEMENTS
}

Authors are range scientists, USDA-ARS, 920 Valley Rd., Reno, Nev. 89512.

\begin{abstract}
The decade of the 1920s was somewhat of a paradox for range science. A. W. Sampson published 3 books that were widely used as text for higher education classes in range management. The United States Department of Agriculture, Forest Service expanded their mandate to manage grazing on National Forest and began to apply the principles of plant ecology and physiology that were being enumerated by range scientists. At the same time millions of acres of public domain outside the National Forest remained as free range and continued to decline in productivity. Progress was made in applying animal behavior technology to improve the uniformity of range forage utilization. This was especially apparent in regard to sheep and goats which were herded on rangelands. The management tools utilized were herding techniques, salt distribution and water developments. Restoration of range productivity and the place of wildfires in range ecosystems remained very controversial subjects.
\end{abstract}

Key Words: herding technology, range text, wildfires, salting, wildfires.

The first 2 decades of the $20^{\text {th }}$ century saw the birth of science as a tool for the management of the western range (Young 2000). By the 1920s range research had grown sufficiently, that it is impossible to comprehensively cover a decade of specific topical or regional research in a single journal manuscript. Our purpose is to portray the status of the range livestock industry and how the science of range management was shaped in its development by the perceived problems of the decade. To accomplish this portrayal we will discuss specific issues and events that highlighted the period. The 1920s are an artificial subdivision of the history of range science, so we will refer back to earlier decades and project into the 1930s on some issues.

\section{Range Science Literature In The 1920s}

Practical range management and the underlying scientific concepts that supported such management began to emerge in the period after 1900. F. E. Clements' Plant Succession: An Analysis of the Development of Vegetation was published in 1916. It was to have a profound influence on the development of range science. Will C. Barnes (1913) published Western Grazing Grounds which certainly served as a guide book for novice forest rangers if not a text for range education. Barnes (1926), as Assistant Forester and Chief of Grazing, Forest Service, United States

\footnotetext{
Manuscript accepted 17 Jun. 2000.
}

\section{Resumen}

La década de 1920 fue algo como una paradoja para la ciencia de manejo de pastizales. A.W. Sampson publico 3 libros que fueron ampliamente utilizados como texto en clases universitarias de manejo de pastizales. El Servicio Forestal del Departamento de Agricultura de los Estados Unidos, amplio su mandato para manejar el apacentamiento en los bosques nacionales y comenzo a aplicar los principios de ecología y fisiología vegetal que estaban siendo enumerados por los científicos en manejo de pastizales. Al mismo tiempo millones de acres de dominio publico fuera de los bosques nacionales permanecieron como pastizal libre y continuo su disminución en productividad. El progreso se realizó aplicando la tecnología del comportamiento animal para mejorar la uniformidad de utilización del forraje del pastizal. Esto fue especialmente aparente en relación con ovinos y caprinos con los que se formaron rebaños en los pastizales. Las herramientas de manejo utilizadas fueron técnica de formar hatos, distribución de saladeros y el desarrollo de aguajes. La recuperación de la productividad del pastizal y el lugar de los fuegos naturales en los ecosistemas de pastizal permanecieron como temas muy controversiales.

Department of Agriculture (USDA), also compiled The Story of The Range which was the result of hearings held by the Senate Committee on Public Lands and Surveys of the $69^{\text {th }}$ Congress. This is an excellent assessment of the status of rangelands in the mid 1920s and served as a precedent for the more comprehensive and influential The Western Range carried out a decade later (Anon. 1936). Published as a long and detailed USDA bulletin, Range Management on the National Forest by Jardine and Anderson (1919) provided the first handbook for practical range management. A major threshold in range science was crossed with the trilogy of text books published by Arthur W. Sampson (see Young 2000 for biographical information on Sampson).

\section{Arthur W. Sampson}

The USDA, Forest Service established its first range experiment stations in the Great Basin with A. W. Sampson as director. Before becoming the director of the initial research station, Sampson had conducted research on restoring degraded subalpine sheep ranges in northeastern Oregon.

Sampson was the most prolific range scientist of the first 2 decades of the $20^{\text {th }}$ century, communicating through USDA bulletins, popular articles and an occasional scientific journal article as his medium of communication (Young 2000). He left the USDA, Forest Service during the early 1920s and became a professor of range management in the School of Forestry at the University of California at Berkeley. A major publication of his 
Forest Service research, Grazing Periods and Forage Production on the National Forest, did not appear until the mid 1920s (Sampson and Malsten 1926). His trilogy of text books were: Range and Pasture Management (1923), Native American Forage Plants (1924), and Livestock Husbandry on Range and Pasture (1928). His forte was the ability to apply knowledge of the plants and animals to manage an agricultural production system based on rangeland resources.

In succeeding decades, as range management grew to encompass all aspects of multiple use management from agronomy to wildlife, the basic goal of the science has become somewhat ill defined and fuzzy. In the founding days of the 1920s, the purpose of range management was to enhance meat and wool production systems based on rangelands.

Sampson's text books on plants and range management were natural outgrowths of his numerous previous publications while he was a scientist with the Forest Service. Because the Forest Service did not conduct research on livestock production, the third text book on livestock production was somewhat a venture into a new field, but obviously a venture that he thought was necessary for the education of future range resource managers. The lack of direct experimental experience with livestock was apparently true in Sampson's case, but not for all early Forest Service range scientists. The Great Basin station was followed by the Jornada and Santa Rita experimental ranges in the southwest. The Jornada Grazing Reserve was established in May 1912 by Presidential Executive Order. In 1915 it became a non-Forest (not located on a National Forest), Forest Service Experiment Station and conducted, in cooperation with the grazing permittee, animal husbandry research (Jardine and Hurtt 1917). Forest Service scientists such as Jardine, Fleming, Chapline, and Forsling, who all spent time at the Jornada, were exposed to animal breeding and nutritional research.

During the 1920s, students in range management classes were primarily forestry majors. In Sampson's obituary, published in the Journal of Range Management, the story was related of how Sampson had to challenge unruly forestry majors, who were un-willing participants in his range management class, to a fist fight in order to get their attention (Anon. 1968).

\section{Growing Cast Of Range Scientist}

James T. Jardine was the first director of
Forest Service range research (Office of Grazing Studies) (Rowley 1985). He conducted research on range sheep grazing in the Wallowa Mountains of Oregon and worked on increasing beef production at the Jornada Grazing Reserve before moving to Washington, D.C. He resigned in 1920 to become Director of the Oregon Agricultural Experiment Station and was replaced by W. R. Chapline.

The Jornada Range Reserve was first under the supervision of Elmer O. Wooton (Anon. 1944). In 1915, non-National Forest range research was transferred from the USDA's, Bureau of Plant Industry to the Forest Service. Charles E. Fleming became the Forest Service scientist at the Jornada. Fleming was born in Odgen, Utah in 1889 . He received a B. S. degree from Utah Agricultural College and a B. S. A. degree from Cornell University. He was appointed a grazing examiner for the Forest Service in 1910. After conducting research at the Jornada and Santa Rita Grazing Reserves, Fleming joined the department of range management at the University of Nevada.

Clarence L. Forsling worked at the Jornada before becoming director of the Great Basin Experiment Station in 1922 after Sampson left the Forest Service. Forsling was born on the family cattle ranch in western Nebraska. He graduated from the University of Nebraska in 1915. He ranked first on the list of applicants for Range Examiner in 1916 and was hired by the Forest Service. He became an assistant to Leon Hurtt who was director of the Jornada Experimental Range, followed by an assignment in Washington, D. C, before moving to the Great Basin station. Charles E. Fleming and William Ridgely Chapline were pioneers in the development of management systems for animals herded on rangelands.

\section{Livestock Industry}

In 1925, for every 100 Americans, there were 57 cows, 34 sheep, 47 hogs, and 15 horses (Sampson 1928). American average per-capita meat consumption was a staggering $69 \mathrm{~kg}$ (152 pounds) while the average for the 22 most developed countries was $41 \mathrm{~kg}$ (90 pounds). Before 1900 the average $\mathrm{T}$-bone steak served in an American restaurant weighed $2.3 \mathrm{~kg}$ (5 pounds) (Young and Sparks 1985). The steak came from an American common or longhorn steer that was marketed at 4 to 6 years of age. By the 1920s the marketing age for steers had dropped to 2 to 3 year old "baby beef". America was a nation of meat eaters. The supply was excellent and relatively cheap. Texas was the leading range livestock state, closely followed by California.

Sampson considered the western livestock boom to have occurred from 1840 to 1900 (Sampson 1928). He thought the demand for forage had subjected vast areas to grazing, which in earlier days had not been considered suitable for husbandry of domestic livestock. The harsh winters on the Great Plains (1886) and west of the Rocky Mountains (1899) and the droughts of the southwest (starting 1893) killed an astounding number of livestock. In 1926 livestock numbers on the western range had fallen to an estimated $30 \%$ below the potential original carrying capacity because of degradation of rangeland resources by improper and excessive use (Sampson 1928). Even in the 1920s, USDA estimated that annually 1.1 to 1.4 million cattle died annually on rangelands from diseases (including plant poisoning) and an additional 0.6 to 1.4 million died from exposure. The exposure deaths were brought on by starvation.

The agricultural depression that followed World War I had a devastating influence on American farmers and ranchers. Agricultural producers were very conscious of cost. The Oregon Agricultural Experiment Station, now under the direction of James Jardine, undertook a series of studies on the cost of meat and wool production on rangelands. E. L. Potter (1925) divided the ranches of eastern Oregon into 2 geographic-economic regions. Most of the area east of the Cascade Mountains consisted of relatively small ranches that supported between 100 and 200 head. No ranches had more than 2,000 head and a very few exceeded 500 cows. During 4 months of winter the cows were kept at the home ranch where they grazed on crop aftermath and were fed hay. During the spring and fall they were grazed in fenced pastures in the foothills. Summers were spent in the high mountains either on National Forest or on range leased from timber companies. The exception to the type of operation described above occurred in what Potter called the free range counties of Oregon; Malheur, Harney, and a portion of Lake and Crook Counties located in the southeastern portion of the state.

The free range area covered some 6 million hectares ( 15 million acres) of which about 0.8 million hectares ( 2 million acres) were deeded land where ranch headquarters and hay fields were located. A small portion of the free range belonged to the State of Oregon, largely as school 
support sections. An astounding 0.8 million hectares ( 2 million acres) were abandoned homesteads that had reverted to public domain. All of the far western states had similar ownership patterns, in widely varying proportions, during the 1920s. Nevada had virtually no abandoned homestead land. Even the most naive homesteader hesitated at attempting rain fed agriculture in the deserts of Nevada, but the proportion of free range open to potential homesteading was much higher in Nevada as compared to Oregon.

Potter calculated the cost of running a brood cow for a year on the largely deeded land ranches of eastern Oregon as $\$ 21.40$ and for the free range area as $\$ 16.10$. The cost of hay production was lower in the free range area because it mainly was low quality material produced from native meadows compared to alfalfa (Medicago sativa $\mathrm{L}$.) produced under irrigation in the deeded land area. The big difference in production cost was that the free range ranches did not pay taxes or grazing fees on the public domain rangeland. This had been a major issue since the ranges were first settled and was a major stumbling block in the prolonged struggle to establish some form of range management on the vacant public domain. This struggle did not end until the passage of the Taylor Grazing Act in 1934. Many ranchers in Nevada did not take advantage of opportunities to acquire title to portions of their public domain rangelands through purchase of state select school lands or stock raising homesteads because they believed the economic burden of paying taxes on these lands exceeded the value of the forage they harvested from the lands (Young and Sparks 1985). This became an economic hoax because, as E. L. Potter indicated in the 1920s, both the deeded land and free range ranchers were losing money on every steer they sold if you included in the cost of production interest on the capital investment. During the remainder of the 20th century, except for the relatively short period during and immediately after World War II, inflation in deeded land values was the only economic boom for the small range livestock operation in public land states. This had tragic results for ranches during the Great Depression of the 1930s. Once the Taylor Grazing Act was passed, the value of grazing permits was capitalized into the value of ranches, but by the late 20th century it became all too apparent that these permits were a privilege and not a right.

The value of grazing permits on National Forest was quickly recognized. Barnes
(1913) wrote "The advantages of grazing stock on the national Forest are so apparent that the permit has come to have a great pecuniary value, resulting in a premium on both ranches and stock located within or adjacent to National Forest ranges."

\section{The Role Of Fire}

Looking back on the first half of the 20 th century, it is puzzling why Americans lacked the consensus and the will to come to grips with a policy for the scientific management of the Public Domain that was not regulated by the Forest Service. The management or lack of management of these lands was widely discussed in the press. Glenn Bennion (1924), writing in The National Wool Grower stated, "Sagebrush came when the wasteful, destructive methods of range exploitation, developed as a result of the Government's indefensible free-range policy, destroyed the grass, thus permitting those forms of vegetation that stock canot eat to take the place of grass." Bennion was a resident of Utah and the member of a pioneer ranching family. We found a copy of this article in the files of the late Joseph Robertson. Dr. Robertson was noted for the comments he penciled in the margins of publications. Opposite the above quote from Glen Bennion, appeared the pencil note, "Remember this is a stockman writing, not some of those USDA so \& sos." Bennion proceeded to take pioneer stockmen to task for their unknowing destruction of bunchgrass ranges by prolonged (repeated year after year), season-long, excessive grazing.

Bennion had a simple plan for the restoration of degraded bunchgrass ranges. Burn the ranges during the hot summer months, rest the burned areas from all grazing until the grasses had a chance to recover and then use moderate stocking rates with seasonal, managed grazing. He offered evidence these ranges still supported remnant stands of native perennial grasses that were available to re-stock the stands if given a chance to recover free from brush competition and excessive grazing. Mr. Bennion's article appears to have been a reasonable account of the situation that existed on many foothill ranges in the big sagebrush (Artemisia tridentata Nutt.) zone during the 1920s. However, the next issue of The National Wool Grower featured a letter from C. L. Forsling, Director of the Great Basin Experiment Station of the USDA, Forest Service which went to some length describing the terrible hazards associated with the use of fire in natural resource management. His concluding remarks were, "Generally speaking, fire is an uncertain doctor with a cure more to be avoided than the disease." (Forsling 1924).

Very early in his career, Arthur W. Sampson wrote a letter to the editor of the Breeder's Gazette where, in a near poetic style, he passionately described the evils of wildfires. "A picture more gorgeous than the stately virgin forest of pine spruce, and hemlock, studded with their refreshing glades of green and carpets of gay flowers, was the panorama that greeted the eye at the hill's summit. There in the distance below the tops of the trees were veiled with a white downy sea of smoke clouds whose outlines quickly lost their identity as they ascended" (Sampson 1911). After this introduction Sampson developed a quite academic discussion of types of forest fires including 3 excellent illustrations. Sampson signed the letter as Arthur W. Sampson, District of Columbia. The previous year he had submitted a letter to the editor of the same journal attacking the burning of prairie meadows in Nebraska, aboriginal burning before European contact, and stated the entire west was burning (Sampson 1910). He indicated his return address for this letter as Wallowa, Oregon. It is apparent that at the time, the pioneer range scientist considered wildfires a great evil. More importantly, it is apparent that the basic role of wildfires as a stand renewal process and in nutrient cycling were not understood and appreciated.

Forsling (1924) suggested there were other ways more acceptable for restoring degraded rangelands than using prescribed burning. Arthur W. Sampson (1920) had previously published in the National Wool Grower an article on how to bring back overgrazed range through grazing management. Sampson introduced the concept of deferred and rotation grazing to restore grass to overgrazed range. He stressed that hundreds of artificial seeding trials had been conducted on degraded rangelands with exotic forage species with scant success. In contrast to these failed attempts, grazing management to allow the native grasses to produce seed and establish seedlings was very successful. Sampson's research was largely conducted in subalpine grasslands. The sites Bennion was describing were degraded big sagebrush/bunchgrass sites. Sampson's basic ecological parameters applied to the big sagebrush site, but only after the dominance of the over abundant woody species was reduced. Once sagebrush had increased in abundance, it largely closed the site to perennial grass seedlings for a prolonged 
period of time, perhaps for 100 years in the absence of fire.

\section{Season Of Use}

The classic early paper on proper season of grazing was Grazing Periods and Forage Production On The National Forest by Sampson and Malmsten (1926). As previously mentioned, this Forest Service bulletin did not appear until after Sampson had moved to the University of California. This paper related the physiology of perennial grasses to damage from grazing. Grazing in the early spring before the grasses had the opportunity to renew carbohydrate reserves and flower was very harmful to the persistence of the grasses. C. L. Forsling (1928) expanded on these findings in an article published in a livestock magazine under the title of The Spring Range Problem. Forsling considered that in the mountain and intermountain states of the western United States, spring ranges were generally in poor condition. Much of what previously had been used as spring range was now under cultivation. Farmers wanted the livestock off the fields as soon as possible in the spring so they could conduct necessary agronomic practices such as spring-tooth harrowing alfalfa, brushing (spreading) cow chips and irrigation. Forsling suggested that special pastures should be developed to provide forage during this early spring period. The exotic perennial wheatgrasses (Agropyron spp.) were introduced 2 decades later and sometimes used to fill this forage need, but the problem of early spring forage remains on many former sagebrush/bunchgrass rangelands.

\section{Range Sheep}

Management on the western range continued to suffer in the first 2 decades of the $20^{\text {th }}$ century from the range sheep syndrome. This syndrome blamed everything wrong with forest and range condition on the range sheep industry. The origins of the syndrome date back into the $19^{\text {th }}$ century when the original Forest Reserves were established. Established cattle ranchers were quick to blame all the evils of range degradation on the range sheep and especially on so called tramp sheep operations whose owners did not own commensurate property in a given area of rangeland.

During his review of the Cascade Forest Reserve in Oregon in the 1890s, Frederick Coville of USDA was astounded to find range sheep being closely herded on the range in bands of 1,000 to 2,000 animals (Coville 1898). He blamed trampling damage from sheep for much of the destruc- tion apparent to forested rangelands. After the Forest Service was established and became responsible for the management of Forest Reserves, experiments were conducted with predator proof fencing of timbered rangelands with the objective of grazing sheep without herders or concentration of the animals into bands (Jardine 1910).

The Forest Service appointed a series of range management staff officers for Regional Forests in 1911. For what was then called the Rocky Mountain Region, C. E. Fleming was appointed. Fleming was among the very first to apply livestock management techniques to the perceived problems created from herding sheep on rangelands. Fleming (1915) reported in the National Wool Grower on the "blanket" system of sheep handling practiced in the Madison National Forest of Montana. For a producer's magazine, the article was quite technical with scientific names given for all the plants mentioned. There were no literature citations, but at the time there was virtually no applicable literature to cite. Fleming did mention the studies conducted by Jardine at Billy Meadows in the Wallowa Mountains of Oregon (Jardine 1910). Fleming interpreted Jardine's results as indicating that carrying capacity increased $50 \%$ with free ranging versus closing herding of sheep. Based on this information, Fleming developed what he termed, at various times, the blanket, tepee, or bedding-out of handling sheep on the Madison National Forest of Montana.

The "blanket" or "tepee" designation for the grazing system developed by Fleming, apparently was derived from the herder carrying his bedroll and a canvas tent fly with him daily (Figs. 1 and 2). The key points of the system were: 1) the herder camped where the sheep ended each day and he did not return to the same camp daily, 2) during the day the sheep were allowed to graze peacefully in open bands, and 3) dogs were not used during the grazing period. The herders had to be paid $\$ 50$ dollars per month, double the normal $\$ 25.00$, because of the limited use of dogs and the hardship of no fixed base camp. Fleming described the ideal day as the sheep starting to graze at 0400 to 0500 hours and resting in the shade of timber during the mid-day heat or in the browse along stream banks.

To set the stage for his report to the wool growers, Fleming suggested that the guaranteed open summer range of the National Forest was the potential salvation of the range sheep industry. So much of the previously open range in the plains and foothills of Montana was lost to the sheep industry because of homesteading.

\section{Range Goats In The Southwest}

At nearly the same time that Fleming was developing new sheep management methods in Montana, Forest Service scientists were developing management procedures for goat grazing in the National Forest of the southwest. It was estimated that 50,000 goats grazed on the National Forest of New Mexico and Arizona in 1916 (Chapline 1916). In many portions of the west, ranchers were noticing the condition of ranges was changing. The most common perception was the decrease in herbaceous vegetation, especially perenni-

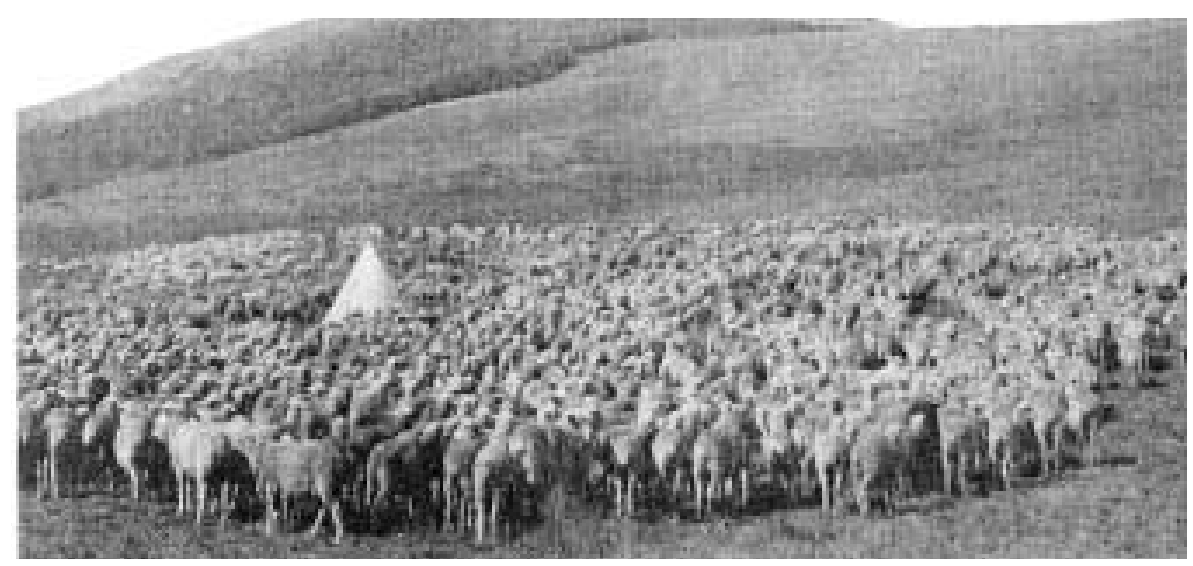

Fig. 1. Illustration of one-night sheep camp where herder pitched his tent where ever the sheep stopped at the end of the day rather than returning to a fixed camp every night. (Fleming 1918). 


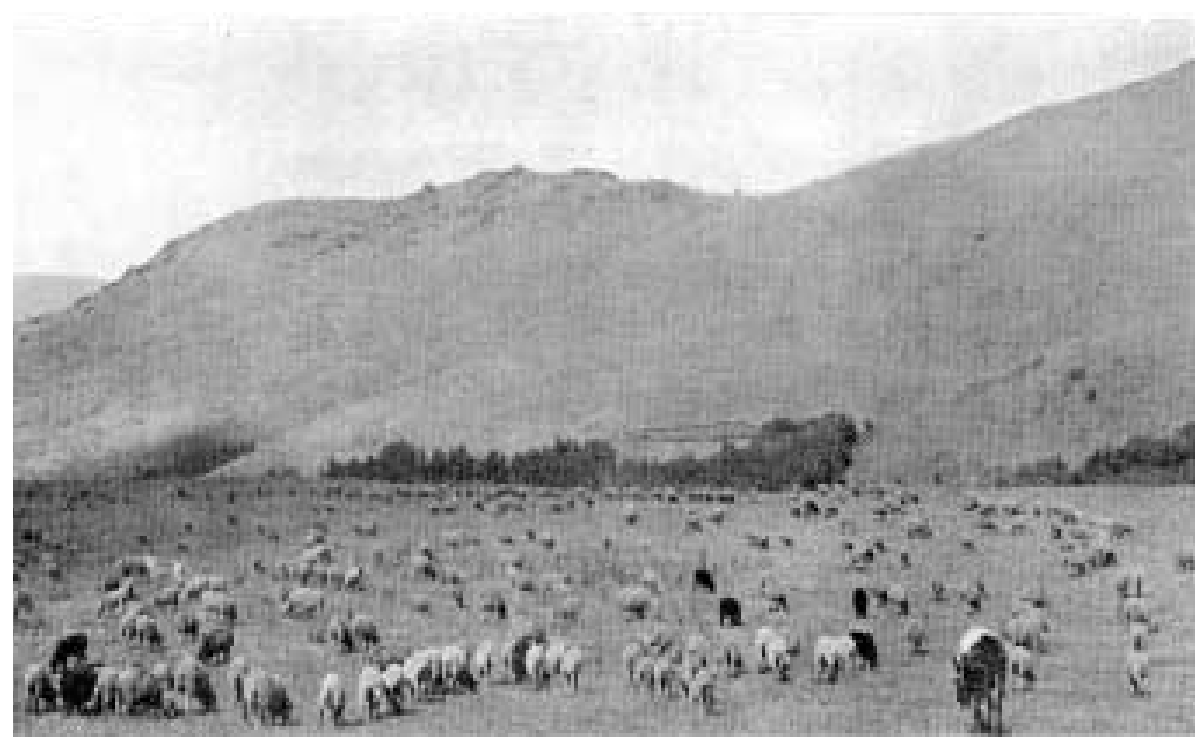

Fig. 2. Illustration of relaxed or open herding of sheep on the range to prevent trampling damage. Herd directed by turning the leaders rather than dogging the tail end of the band (Fleming 1918).

al grasses, and increased dominance by woody vegetation. This perception led ranchers to write letters to editors of newspapers and commodity periodicals describing the losses in forage production and usually calling for the return of burning to National Forest, or more precisely, the end of fire suppression in National Forest.

In the southwest, a different scenario of this increase in brush theme was unfolding. Goat ranchers were sure the answer to increased brush was increased browsing by goats. In 1916 the editor of The Angora Journal published an editorial chastising the Forest Service for not allowing increased goat grazing on the National Forest (Chapline 1916). This prompted Acting Forester A. F. Potter to respond to the editor that the Forest Service was studying goat management and he submitted a manuscript from the Forest Service scientist W. R. Chapline, Jr. to illustrate this research.

Chapline had the longest professional career of the early range scientists. He was born in Lincoln, Nebraska in 1891 and graduated from the University of Nebraska. He progressed from grazing assistant to range examiner with the Forest Service before becoming Director of the Office of Grazing Studies. Chapline was at the Jornada Experimental Range the day Poncho Villa raided across the border into New Mexico.

Chapline made the same management suggestions for goats that had previously been made by Fleming for sheep (Chapline 1916). He called his systems a "several camp" versus the traditional "one camp" method of herding. Chapline (1919) later expanded this manuscript into USDA Bulletin No. 749, which became one of the cornerstone papers of range management.

In the same issue of The Angora Journal a letter appeared from a goat rancher under the headline "Forest Officials Discriminate Against Goat Growers, But Favor Cattle Operations" (Anon. 1916). On the Gila Forest, goat numbers had been reduced from 47,100 to 23,800 while cattle numbers had been allowed to increase. The same rancher complained that since the National Forest was established, wherever he rode on the range there were signs telling him how to prevent wildfires, but there were no signs on how to manage the forage resource.

\section{One-Night Camps}

C.E. Fleming left the Forest Service to become the head of the Department of Range Management at the University of Nevada. He published 2 bulletins on range sheep management, with the same title "One-Night Camps vs. Established BedGrounds On Nevada Sheep Ranges" (Fleming 1918, 1922). Note that he had dropped his "blanket" or "tepee" management and adopted Chapline's 1-night designation for preferred management. Fleming based his bulletins on actual experimentation. He described the experimental area as nearly tree-less mountain ranges where the vegetation consisted of $75 \%$ perennial grass, $20 \%$ weeds (broadleaf native plants we would now refer to as forbs), and 5\% browse. He indicated that utilization averaged an astounding $93 \%$ of the annual forage production.

Fleming made the basic comparison of established camps to which the sheep were herded nightly and the sleeping-out, 1night system where a new camp was used every night. The nightly moving camp was only part of the contrasting system. Of more importance was the relaxed way the sheep were allowed to graze during the day, with open bunches and limited or no dogging (tightly bunching the animals with the help of sheep dogs) of the animals. Fleming measured the success of 1night herding both in terms of reduction in trampling and over-grazing damage and in increased wool and mutton production. Vegetation sampling was accomplished by an extensive set of paired plots on bedding grounds. Using bands of 1,500 ewes and lambs each, the open herded, one-night camp band out-produced the traditional herded band by over $3,632 \mathrm{~kg}(8,000$ pounds) of mutton during a summer grazing season.

In 1928 the Utah Agricultural Experiment Station published a quite comprehensive bulletin on the range sheep industry (Esplin et al. 1928). The only mention of Fleming's research was a terse sentence indicating that if you camped more than 1 night in the same place with a band of sheep on the National Forest you were going to pay penalties.

\section{Salting}

Distribution of livestock on rangelands was perceived by early range scientists as a major problem in obtaining proper grazing management. During the 1920s, most of the rangeland was open with minimal fencing. Watering points were limited and expensive to develop. Topography often was a restraint on the distribution of grazing animals. For sheep and goats, modification of herding practices could be used to obtain improved distribution. For cattle and horses, their natural craving of the grazing animals for salt (sodium chloride) could be exploited to obtain improved livestock distribution (Chapline and Talbot 1926).

Obviously, there are great differences in the salt requirements for livestock in different locations in the west. On the salt desert winter ranges of the Great Basin, many of the native shrubs, such as black greasewood (Sarcobatus vermiculatus [Hook.) Torr.), got rid of excess salts by shunting them to deciduous fruits and leaves which livestock licked from the soil surface. On summer ranges in the high 
mountains, during succulent feed periods, forage would be deficient in salt. The issue in livestock management was not so much a problem in dietary deficiency as it was the craving livestock exhibited for sodium chloride and the potential this craving offered for modifying animal behavior. Chapline and Talbot (1926) placed salting in the perspective that the potential benefits in improved distribution were so great and the cost of artificially provided salt licks so low, range managers were foolish not to use proper salting methods. They placed the average annual salt requirement for cows at 20 pounds, and sheep and goats 3 to 4 pounds.

The natural tendency among stockmen was to place the salt where the livestock concentrated at watering points. This was based on the assumption that the animals needed the supplement so it should be placed where it could be easily found. This essentially enhanced the concentration of livestock around watering points and therefore added to the over utilization of vegetation.

Before the advent of salt pressed into blocks, the only stock salt available was the coarse ground "hay" salt, so called because farmers used it to prevent the spoilage of hay with excessive moisture content. Rock salt could be used, but it was injurious to the teeth and mouths of livestock. The losses from moisture and wildlife use of coarse ground salt, meant that ranchers had to have cowboys riding a salting circuit virtually the entire grazing season. To reduce losses of salt and to prevent the trampling and pawing damage associated with placing salt on the ground, Chapline and Talbot stressed the construction of boxes for the placement of salt. Considering the remote, roadless conditions of most National Forest rangelands, these salt $\operatorname{logs}$ were chopped from logs available on the site. Prospective applicants wishing to take the Civil Service test for employment as a Junior Range Examiner with the USDA, Forest Service had better be prepared on the hewing of salt logs. Pressed 50 pound blocks of salt replaced granular bagged salt. Sampson (1923) objected to the pressed blocks because of the time required for livestock to satisfy their salt needs by licking the blocks as opposed to consuming the granular salt. The blocks were also a mixed blessing for those who had to lash the dense, slippery blocks with beveled corners to a pack saddle.

The value of salting plans for enhanced livestock distribution lay in their cheapness of application and their immediate effec- tiveness, although they could not be expected to correct all the natural faults associated with proper livestock distribution (Jardine and Anderson 1919). As we enter the 21 st century it is not very difficult to drive about anywhere on the western range and still find salt or other supplement stations located at watering points.

\section{Stock Water}

Jardine and Hurtt (1917) stressed the importance of well-planned water supplies for rangelands. On the Jornada Range Reserve they considered that cattle should not have to travel more than $21 / 2$ miles for water. They reported that during the drought of 1916 cattle outside the Jornada Reserve were forced to go so far from water to find forage they arrived back at water in a weakened condition and when they returned to water they drank and died. Water was the key in obtaining even distribution of grazing.

The development of stock water in the southwest was the subject of a much more detailed treatment by M.W. Talbot (1926). He reported that ranchers and the Forest Service had spent $\$ 750,000$ on the development of stock water in the 14 National Forests of the southwest. Talbot stressed that further development of water would not lead to more livestock on the National Forest, but to more even utilization of the existing forage resources and a reduction in excessive grazing near existing water.

In the southwest, ranchers usually considered about one third of their cows watered every day. This went up to $100 \%$ of the cows during hot dry weather. During periods of succulent forage, sheep could go for extended periods without water. Talbot (1926) introduced the role of topography in determining the correct spacing of watering points. On rolling topography, 1 watering point might be sufficient for 500 cows, while in steep, rugged topography one watering point would suffice for only 50 cows.

\section{Conclusion}

Obviously, range science was growing and becoming defined during the decade of the 1920s. A. W. Sampson's 3 books provided texts for range management courses in the western schools of forestry. Livestock management systems were proposed to solve the lingering problem of management of herded sheep and goats on rangelands. Modification of the behavioral patterns of range livestock with distribution of salt and watering points became foundations of range management.
Despite the advances in range science, the range livestock industry remained mired in economic depression. There was endless debate, but no agreement on who was to manage the vast areas of unappropriated public lands. There was no lack of proposals on how to dispose of or manage the unappropriated lands. The Forest Service was proposed as the management agency for these lands. Elmer O. Wooton, the pioneer botanist in New Mexico and the first director of the Jornada Grazing Reserve, became involved in Nevada with a proposal to divide the unappropriated public domain among ranchers based on the ownership of stock water sources (Young et al. 1998). Currently, Federal, versus State or private ownership of water rights on public domain remains a volatile issue.

A. W. Sampson (1928) devoted a chapter in his book Livestock Husbandry On Range and Pasture to wildlife resources on rangelands. This was a major departure from most of the previous range science literature. In the next decade wildlife-livestock interactions were to become a major issue. Sampson credited Joseph Grinnell (1924) with the pioneer publication on wildlife on the western range.

It is interesting to contemplate if anyone involved during the 1920 s with the western range and livestock industry, had any inkling of the Great Depression, regional droughts, and social change that were waiting to occur during the 1930s.

\section{Literature Cited}

Anon. 1916. Claims that forest officials discriminate against goat growers, but favor cattle raisers. The Angora J. 5(7):7.

Anon. 1936. The western range. Senate Doc. 199. U. S. Senate Committee on Public Lands and Surveys, G.P.O., Washington, D.C.

Anon. 1944. The history of range research. Agr. History 18:127-143.

Anon, 1968. Arthur W. Sampson (obituary). J. Range Management 20:103.

Barnes, W. C. 1913. Western grazing grounds. Breeder's Gaz., Chicago, Ill.

Barnes, W. C. 1926. The story of range. U. S. Senate Committee on Public Lands and Surveys, $69^{\text {th }}$ Congress, G.P.O., Washington, D.C.

Bennion, G. 1924. Re-grassing the range. The National Wool Grower. 14(6):19-21.

Chapline, W. R., Jr. 1916. Goat management on the National Forest in the southwest, including a description of the "one camp" and "several -camp" methods. The Angora J. 5(7):3-7.

Chapline, W. R. 1919. Production of goats on far western ranges. Bull. 749. USDA, Washington, D.C. 
Chapline, W. R. and M. W. Talbot. 1926. The use of salt in range management. Cir. 379, USDA, Washington, D. C.

Clements, F. E. 1916. Plant succession: an analysis of the development of vegetation. Publ. 242, The Carnegie Inst., Washington, D.C.

Coville, F. V. 1898. Forest growth and sheep grazing in the Cascade Mountains of Oregon. USDA, Div. of Forest. Bull. No. 15. Washington, D.C.

Esplin, A. C., W. Peterson, P. V. Cardon, G. Stewart, and K. C. Ikler. 1928. Sheep ranching in Utah. Bull. 204, Utah Agr. Expt. Sta., Logan, Ut.

Fleming, C. E. 1915. "Blanket" system of handling sheep on the Madison National Forest. The National Wool Grower 5(5):7-10.

Fleming, C. E. 1918. One-night camps vs. established bed-grounds on Nevada sheep ranges. Bull. 94, Agr. Exp. Sta., Univ. Nevada, Reno, Nev.

Fleming, C. E. 1922. One-night camps vs. established bed-grounds on Nevada sheep ranges. Bull. 103, Agr. Exp. Sta., Univ. Nevada, Reno, Nev.

Forsling, C. L. 1924. Fire and range improvement problem. The National Wool Grower 24(7):14.
Forsling, C. L. 1928. The spring range problem. The Producer 10(5):3-7.

Grinnell, J. 1924. Wild animals as a product and as a necessity on National Forest. J. Forest. 22:

Jardine, J. T. 1910. The pasture system for handling range sheep, investigations during 1909. USDA, Forest Serv. Cir. 178, Washington, D. C.

Jardine J. T. and M. Anderson. 1919. Range Management on the National Forest. USDA, Bull. 790, Washington, D.C.

Jardine, J. T. and L. C. Hurtt. 1917. Increased cattle production on southwestern ranges. Bull. 588, USDA, Washington, D.C.

Potter, E. L. 1925. Cost of producing beef on the ranges of eastern Oregon. Bull. 220, Oregon Agr. Exp. Sta., Corvallis, Ore.

Rowley, W. D. 1985. U. S. Forest Service grazing and rangelands. Texas A \& M Univer. Press, College Station, Tex.

Sampson, A. W. 1910. Burning hay-meadows and grazing lands. Breeders Gaz. 59:352.

Sampson, A. W. 1911. Concerning forest fires. Breeder's Gaz. 60:429-430.

Sampson, A. W. 1920. Bringing back overgrazed range. The National Wool Grower 10(4):11-14.
Sampson, A. W. 1923. Range and pasture management. John Wiley and Sons, New York, N.Y.

Sampson, A. W. 1924. Native American forage plants. John Wiley and Sons, New York, N.Y.

Sampson, A. W. 1928. Livestock husbandry on range and pasture. John Wiley and Sons, New York, N.Y.

Sampson, A. W. and H. E. Malmstem. 1926. Grazing periods and forage production on the national forest. Bull. 1405, USDA, Washington, D.C.

Talbot, M. W. 1926. Range watering places in the southwest. Bull. 1358, USDA, Washington, D.C

Young, J. A. 2000. Range research in the far western United States: the First Generation. J. Range Mange. 53:

Young, J. A. and B. A. Sparks. 1985. Cattle in the cold desert. Utah State Univer. Press, Logan, Ut.

Young, J. A., Fay Allen, and C. D. Clements. 1998. The Wooton plan-division of Nevada rangelands based on water. Rangeland Manage. and Water Resources, Amer. Water Resources Assoc., Spec. Confer., Reno, Nev., pp. 293-298. 